\title{
Moslem Theologian and Environment: The Confirmation of Power, Knowledge, and Ecologic Awareness of Moslem Theologian in Martapura
}

\author{
Laila Azkia \\ Sociology Anthropology Education Department \\ Faculty Teacher Training and Education \\ Universitas Lambung Mangkurat \\ Banjarmasin, Indonesia
}

\begin{abstract}
This study discusses about knowledge of Moslem Theologian in Martapura about environment. This study aims to investigate the forming process of ecologic awareness. The significance of this study is as learning material in the field of knowledge sociology, religion sociology, and environmental sociology, especially human ecology. This study used knowledge sociology perspective in which the researcher knows the forming process of ecologic awareness through subject's knowledge. Based on knowledge sociology, someone's knowledge cannot be separated from his/her existence. Therefore, the researcher tried to obtain comprehensively about subject's existence in the name of him/herself. The researcher knows the forming of ecologic awareness by seeking how subject gives a meaning to her/himself, human and environment, namely the relationship between human and nature. The method used in this study was qualitative method with phenomenology approach using direct interview towards research subjects. Data were taken by observing subjects, comprehensive interview and simple method of life history. There are two kinds of subjects used in this study, namely an expert informant and 3 supporting informants
\end{abstract}

Keywords-moslem theologian, knowledge, ecologic awareness

\section{INTRODUCTION}

Local government of South Kalimantan Province seems to act slowly in overcoming land firing problem which becomes more critical. They undergo obstacles in solving the problem. Up-down socialization about the danger of opening land by firing forest has been done by government, but it does not bring the expected result. Therefore, they ask MUI (Majelis Ulama Indonesia / Forum of Indonesian Moslem Theologian) in South Kalimantan to release official religious advice containing that opening land by firing forest is forbidden. This advice is based on loss caused by forest firing such as destroying and disturbing public facilities, and causing pollution and thick smoke. The government through MUI tries to change community's point of view toward the nature. This effort is done by using power of Moslem Theologian

\section{LITERATURE REVIEW}

Religion has to be involved in overcoming environmental problem because Evelyn Tucker in "Menanam Sebelum
Kiamat", states that there are at least 5 fundamental principles owned by religion to save the nature that commonly called as 5R: (1) Reference or belief acquired from textual sources (holy books) or their own belief, (2) Respect, appreciation towards all living material taught by religion as God's creation. (3) Restrain, ability to manage and control materials in order to be beneficial, (4) Redistribution, ability to spread richness, happiness, and philanthropy through charity activities, (5) Responsibility, responsibility in taking care of environmental and natural condition. Therefore, the role of religion is very important in natural reserves. However, the problem is how to convey message of conserving the nature to the religion's followers. It is Moslem Theologian's duty to convey the message.

Because of the urgency and fundamental role of Moslem Theologian in nature conserving effort, it is important to know the forming process of ecologic awareness in Moslem Theologian.

The objective of this study was to investigate the forming process of ecologic awareness among Martapura Moslem Theologians. This process is known through knowledge sociology analysis of Karl Mannheim. Knowledge sociology becomes the main theory in this study. The major assumption of knowledge sociology is that knowledge and the existence of a person who owns it cannot be separated.

This study used knowledge sociology perspective to enable the researcher to know the forming process of ecologic awareness through subject's knowledge. Based on knowledge sociology, someone's knowledge cannot be separated from his/her existence. Therefore, the researcher attempted to obtain subject's existence comprehensively. The researcher tried to find the forming of ecologic awareness by seeking how subjects give a meaning to themselves, human and environment, which include the relationship between human and nature.

Through analysis toward individual that has knowledge, the researcher attempted to dig subjects' awareness about their social status and position and also subjects' awareness due to 
relationship between human and environment. Through these points, the researcher analyzed it as a meaning stage about how forming process of ecologic awareness was conducted. It must be kept in mind that ecologic awareness is related to environmental ethics.

The purpose of this research is to know about environment view of Martapura's moslem theologian, it's important because the environmental view is determinant behavior of moslem theologian. I want to know about how a formation process ecologic awareness of Martapura's moslem theological. Knowing a formation process of ecological awareness is important with assumption that awareness is not formed by chance and is formed by something other than himself, it's a phenomenology method assumption. Aspect of awareness we research is social awareness, it's how a awareness about something effected od people around include a experienced. According to the Carl Gustaf Jung, a psikolog from Swiss, someone historical depend on a specific experience in someone historical awareness, is a historical regeneration from one generation to other generation by regeneration [1].

Ecological Awarness is a primary point in this research. Ecological awareness from two word is awareness and ecological. A word ecological is from a filsuf and biologist the name is Ernest Haeckel. The definition of ecological is a study about relation living things with environment as a household [2]. Poedjawijatna [3] said awareness is conscious based on knowledge, is knowledge about the awakening of the soul to something, conscious and know is the same.

Ecological Awareness is understand feeling about relation which should and should be intertwined between living things with environment in a world ecosystem. Deep ecological awareness is spiritual awareness [4]. Ecological awareness is about human awareness, awareness of position with the environment or nature, human interwoven with nature, human interconnection with nature, and most importantly. Ecological awareness also means human consciousness that it is not more important than plants, animals, and other creatures on earth.

\section{METHOD}

The method used was qualitative method with phenomenology approach, especially transcendental phenomenology in which the researcher tried to analyze and obtain comprehensive picture through interview towards subjects. To analyze the data in this study, the researcher referred to Mustaches with phenomenological data analysis in the form of horizonalization. It is a process to explore the deepest meaning of subjects' utterance during the interview.

\section{RESUlt AND DisCUSSION}

The Result of this research is First Moslem Theologian is a person who understand environmental problem. Moslem Theologian adheres to ethics not only one but two. It is because Muslim theologian action depends on religion. And Islamic religion has two meaning about environment, one is anthropocentric and the second is deep ecology. Second, Moslem Theologian decides silent because he keeping trusts a society who always hears his speak. Third, a Muslim theologian has a power and authority to influence people who always hear him, but he not utilized because speak about environmental is not fortune for him position and strata in society. Subject or informant in this research has concept and real understanding about relation between human and environment, but he agree that his position do not duty to speak or show up about environmental problem to her audience. Not only do not duty but also he feel he hasn't right to speak about environment. Fourth, process in formed ecological awareness is process to understand about a harmonic relation in world, it is from interpretation of Islamic religion. Interpretation of Islamic religion about environment it's from him knowledge and existence, its mean subject has awareness about who is him, a position and a social strata impact a power.

Environmental ethics embraced by the subjects in this study is not solely one. The subjects have a view that orients to anthropocentric environmental ethics, but they also have a view which is suitable with ecocentric view. Non single character ethics owned by subjects is related to subjects' own knowledge sources. This source is religion, in this case is Islam. Islam itself is religion which has a high anthropocentric view, but this anthropocentric does not orient to egoistic but egality which becomes basic of ecocentric environmental ethics.

The results of this study showed that subjects' knowledge about environment comes from religion knowledge and experiences. However, their environmental knowledge is not used as teaching material or being spread to learning forum. It is done related to their power, which is their social status and position. The subjects were aware about their social status and position so that they choose to put to silence related to environmental problem. The subjects follow non single environmental ethics, namely anthropocentrism and egocentrism values in themselves. It is caused by their interpretation about Islam. Islam is multi-interpretation religion in which there are anthropocentric, biocentric, and ecocentric values.

Sociology knowledge be a tool of this research to know about environmental perspective of research subject. Environmental perspective of someone not absolutely one. Someone can have two environmental perspective. It is depend on knowledge, experiment and his position or strata.

\section{CONCLUSION}

Although the subjects socially have status that is able to influence community because of prestige as Moslem Theologian, they do not use that authority in relation with environmental problem. Subjects with anthropocentric which tends to be ecocentric do not employ their authority for warning community about environmental problem. It is due to prestige authority problem related with their social status and 
position. Subjects aware that their existence as people given authority and power by community must keep community assessment carefully towards themselves. It is done to keep and maintain the social status and position. Therefore, the subjects prefer to keep silence about environmental problem.

\section{REFERENCES}

[1] MIF. Baihaqi, Psikologi Pertumbuhan, Bandung: PT. Remaja Rosda Karya, 2008.

[2] N. Sumaatmadja, Studi Lingkungan Hidup, Bandung: Alumni, 1989.

[3] A. Neolaka, Kesadaran Lingkungan, Jakarta: Rineka Cipta, 2008

[4] F, Capra, The Tao Of Physic, Menyingkap Pararelisme Fisika Modern dan Mistisisme Timur, Yogyakarta: Jalan Sutra, 2000.

[5] P. L. Berger, and Thomas Luckman, Tafsir Sosial Atas Kenyataan, 